\section{Does Islamic microfinance contribute to economic empowerment in Tunisia?: a case study of Zitouna Tamkeen}

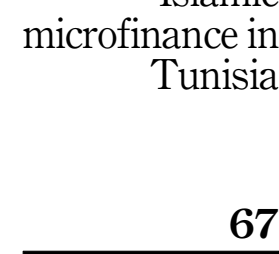

\author{
Takwa Zitouni
}

Universite Ez-Zitouna Institut Superieur de Theologie, Tunis, Tunisia, and

Khoutem Ben Jedidia

ISCAE, Research Unit in Islamic Economics and Finance, Manouba University, Manouba, Tunisia

\begin{abstract}
Purpose - Islamic microfinance is a substantial tool for poverty alleviation and economic empowerment. The paper aims at accessing the potential of Islamic microfinance for the purpose of achieving the economic empowerment in Tunisia.

Design/methodology/approach - A structured questionnaire survey method is used. The method is intended for some of the beneficiaries of Zitouna Tamkeen (ZT), the only Islamic microfinance institution in Tunisia. Responses are analyzed using the statistical package for the social sciences program.

Findings - The authors infer that though the Islamic and conventional microfinance have similar objectives, the methods are different. What is more, the economic empowerment requires not only financial inclusion and entrepreneurship, but also skill development. The results of the survey reveal that ZT has contributed to certain economic empowerment of most of ZT's beneficiaries. In addition, the authors bring to the fore that providing supportive infrastructure and investment is a prominent component of the economic empowerment process.

Research limitations/implications - In the paper, the sample is limited.

Practical implications - The authors have highlighted that some structural barriers to entrepreneurship such as legal, operational and marketing challenges - need to be addressed in a practical way.

Originality/value - This paper establishes the relationship between the Islamic microfinance and economic empowerment. The current paper is the first investigation in this field in Tunisia.
\end{abstract}

Keywords Economic empowerment, Financial inclusion, Islamic microfinance, Tunisia

Paper type Research paper

\section{Introduction}

The economic empowerment and financial inclusion are among the challenges faced by policymakers in developing countries, particularly those with high rates of poverty and unemployment (Demirguc-Kunt et al., 2017).

The Organization for Economic Co-operation and Development (OECD) defines economic empowerment as " the capacity of women and men to participate in, contribute to and benefit

JEL Classification - G21, I38, Z12

(C) Takwa Zitouni and Khoutem Ben Jedidia. Published in Journal of Business and Socio-economic Development. Published by Emerald Publishing Limited. This article is published under the Creative Commons Attribution (CC BY 4.0) licence. Anyone may reproduce, distribute, translate and create derivative works of this article (for both commercial and non-commercial purposes), subject to full attribution to the original publication and authors. The full terms of this licence may be seen at http:// creativecommons.org/licences/by/4.0/legalcode

The authors are grateful to Hichem Ben Youssef, the Economic Empowerment Regional Support Unit Manager in Zitouna Tamkeen for his help in the collect of data.
Received 23 October 2021 Revised 21 December 2021 Accepted 25 January 2022 
JBSED

2,1

68

from growth processes in ways which recognise the value of their contributions, respect their dignity and make it possible to negotiate a fairer distribution of the benefits of growth" (2011, p.6). Thereby, economic empowerment is an effective avenue for poverty alleviation.

In this regard, microfinance can be a leading tool for economic empowerment (Khan and Beg, 2010; Abbas and Shirazi, 2015). Since the poor have difficulty providing collateral, they are considered as "non-credit worthy" and high risk and they are excluded from the formal banking system (Beck, 2015). Microfinance is an important and appropriate catalyst for the development of the majority of poor rural households (Barman et al., 2009). For instance, through microfinance, people are given the opportunities to borrow, save, invest and benefit from the development activities.

However, as argued by Ashraf (2014), the participation of the rural poor in microfinance institutions is affected by religious values. Due to interest charges, $20 \%$ of the poor in some Muslim-majority countries do not take part in microcredit programs (Cameron et al., 2021). Thus, Islamic microfinance could be a solution to this issue. Overall, Islamic finance seeks to achieve social justice and welfare as indicated in Maqasid al-Sharia'h (Iqbal and Mirakhor, 2017). Moreover, the idea of empowerment is vital in the foundation of the Islamic microfinance. Nonetheless, in their bibliometric review of the literature on Islamic microfinance, Hassan et al. (2021) note that while principles, performance and issues of Islamic microfinance and women's empowerment are among the four main topics in this field, [1] few studies combine the two.

In Tunisia, the emergence of Islamic microfinance began with the foundation of "Zitouna Tamkeen," in 2016, the unique Islamic microfinance institution. In 2019, the number of beneficiaries of economic empowerment projects for microfinance from ZT reached about 140 beneficiaries. Furthermore, it is the first financial institution institutionalizing the economic empowerment-financing going beyond financial inclusion to economic inclusion.

The purpose of this study is to investigate the contribution of Islamic microfinance to the economic empowerment approach. Our research focuses on an in-depth case study of ZT. In fact, we discuss how Islamic microfinance can support economic empowerment. Moreover, we use a structured questionnaire survey method with a view to test whether the Islamic microfinance is associated with the economic empowerment with respect to income, productivity and living conditions for a sample of $50 \mathrm{ZT}$ beneficiaries interviewed during the period of April-May 2020. To the best of our knowledge, no study has examined the link between the Islamic microfinance and economic empowerment in Tunisia. Thus, this study attempts to bridge this gap.

The remainder of this paper is as follows. Section 2 presents the conceptual framework of Islamic microfinance and economic empowerment. Section 3 sets forth the empirical study looking into what extent $Z T$ affords the economic empowerment of some recipients. Eventually, Section 4 draws conclusions.

\section{Conceptual framework: Islamic microfinance and economic empowerment}

In this section, we display Islamic microfinance features compared to conventional ones. Then, we discuss how the Islamic microfinance can actively contribute to the economic empowerment.

\subsection{Islamic microfinance features}

Microfinance refers to the provision of financial services such as loans, savings and insurance to micro-entrepreneurs or small businesses in order to improve their standards of living (World Bank, 2007) [2].

Islamic microfinance is the "process of providing small-scale financial services, based on Shariah concepts, to the poor who may be excluded from formal financial services, without putting any burden on the parties either in the form of interest or undue benefits" 
(Hassan et al., 2013, p.330). Hence, the process should adhere to the principles of interest ban, gharar ban, maysir ban, the profit-and-loss sharing and the asset backing principle. It offers asset-based financing such as Musharakah, Mudarabah and Salam. As highlighted by Rahayu (2020), Islamic microfinance has addressed some issues with exciting conventional microfinance including the non-conformity to Islamic values and principles. Indeed, using the structural equation model, Mansori et al. (2020) conclude that religiosity has the highest impact on the individuals' intention to join Islamic microfinance products. Islamic microfinance can provide an alternative to conventional microfinance programs (Alkhan and Hassan, 2021). Banks serve communities less (Asutay, 2010). Faced with this social failure, several authors, such as Asutay (2012), suggest the importance of the Islamic microfinance development to meet the ethical expectations of the Islamic moral economy and to serve the social and development needs of poor/middle-class groups making up the majority of Muslims. Considering the case of Kyrgyzstan, Alkhan and Hassan (2021) evince that the Islamic microfinance is serving "many key aspects of maqasid al-shari'a including: (1) Poverty reduction (2) economy enhancement (3) enhancing social condition of society (4) wealth distribution and circulation, and (5) enhancing intellectual levels of society" (p.57).

Both the Islamic and conventional microfinance have similarities in terms of goals (Obaidullah, 2008). They advocate the entrepreneurship and the human capacity building. They aim to contribute to the socio-economic development, financial inclusion, etc. Nevertheless, there are some differences between them (see Table 1). They are as follows:

(1) Although the conventional microfinance has adopted the mode of interest-based debt financing, the Islamic microfinance provides various financing tools (asset-based financing) to meet the needs of the poor (Nur Indah Riwajanti, 2013), including profitand-loss sharing schemes (Rahman, 2010).

(2) Unlike the conventional microfinance, the Islamic microfinance has more opportunities to use other external funds from charities (zakat, waqf, etc.), so the extremely poor are not deprived of financing. Conventional microfinance is not usually appropriate for the chronically poor and destitute (Rahayu, 2020). Ghlamallah et al. (2021) point out that the integration of zakat and waqf in the Islamic microfinance model is a specific "Islamic approach to philanthropic and inclusive finance."

(3) In the Islamic view, the social approach is not separated from the economic one, which means that the financial inclusion is related to the social inclusion (Abd Elrahman, 2015). Therefore, Islamic microfinance is perceived as less burdensome, since it does not charge high costs as conventional microfinance (Abbas et al., 2014). For instance,

\begin{tabular}{|c|c|c|}
\hline & Conventional microfinance & Islamic microfinance \\
\hline Reference & $\begin{array}{l}\text { Based on capitalism } \\
\text { principles }\end{array}$ & Based on Islamic finance principles \\
\hline Aim & Economic development & Economic and social development \\
\hline Financing mode & Debt -based & Asset-based and profits-and-losses sharing approach \\
\hline $\begin{array}{l}\text { Dealing with } \\
\text { defaults }\end{array}$ & Charges delay penalties & No delay penalties \\
\hline Group targeting & $\begin{array}{l}\text { Targets the active poor } \\
\text { notably women }\end{array}$ & $\begin{array}{l}\text { Targets the active and extremely poor: The poor family } \\
\text { without distinguishing between men and women }\end{array}$ \\
\hline Source of funds & $\begin{array}{l}\text { External funds savings of } \\
\text { clients }\end{array}$ & External funds savings of clients charity funds (zakat, waqf) \\
\hline
\end{tabular}

Source(s): Table established by the author based on Ahmed (2002) and Rahayu (2020)

Islamic microfinance in Tunisia 
JBSED

2,1

70 because Islamic charity funds such as zakat and waqf subsidize to absorb operational costs, the financing price is lower at more affordable levels. Tisdell and Ahmad (2018) argue that the prohibition of interest avoids the social exploitation of the poor.

(4) In contrast with conventional microfinance, there is no penalty in the case of defaults. Begum et al. (2019) explain that if debtors are in difficulty, Islamic microfinance allows the repayment period to be extended at no additional cost. Islamic microfinance is "the best financial facility" to obey to the demand of most of Muslims in both developing and developed nations (Shinkafi et al., 2020).

(5) When targeting the borrower, the conventional microfinance gives priority to women in the provision of loans (Kulkarni, 2011) [3]. However, the target of empowerment is "family empowerment" in Islamic finance (Obaidullah, 2008; Rahayu, 2020). This means that it ensures the economic and social well-being of the family as a whole unit. Islam supports actions increasing the welfare of families (Chowdhry, 2006).

Even though the supply of Islamic microfinance has grown rapidly, it remains quite small (Tisdell and Ahmad, 2018). The study of Abbas and Shirazi (2015) provides evidence that Islamic microfinance is constrained by the lack of knowledge, experience and professionalism of the supporting staff. The study of the World Bank Group (2017) substantiates that Islamic microfinance faces some issues of insufficient financial resources, high set-up and administrative costs, a poor business model and an inadequate regulatory framework. For the Nigerian case, Abdullahi and Othman (2021) give proof that the capital structure, asset size, financial innovation, good risk management and corporate governance frameworks constitute the major determinants of the financial sustainability of Islamic microfinance banks.

\subsection{The relationship between the Islamic microfinance and economic empowerment}

Scholars view the term "empowerment" differently (Rahman et al., 2017). Given the multidimensional aspect, Mukherjee (2015) accentuates that the measurement of empowerment depends notably on "how we deal" with the idea of empowerment and which dimension of empowerment has been chosen to pay particular attention to. Then, there is no single model for empowerment as long as institutional strategies to empower poor people will vary, depending on the political, institutional and cultural context.

Empowerment is based on four key elements: access to information, inclusion/ participation, accountability and local organization (Narayan, 2007). That being so, the economic empowerment supposes a shift from financial inclusion to economic inclusion through establishing an economic value chain providing the supportive ecosystem as highlighted by Jouti (2019). Working in an ecosystem would enable all the stakeholders to make optimum use of financial resources and to define indicators with the aim of monitoring the impact, identifying the gaps and adopting the corrective measures. Empowerment is critical, as the poor are vulnerable owing to multidimensional factors. As a matter of fact, they lack access to economic opportunities, financial resources, required environment to be able to work efficiently, safety nets in the case of shocks or life events and networks to acquire inputs or to sell outputs (Karim et al, 2008).

Microfinance can promote economic empowerment through its financing impact and the value chain implementation. For instance, it guarantees the sustainability of projects as it offers complete solutions for all obstacles (business opportunity, finance, supportive investment, etc.) and not only cash solutions. Non-financial interventions are critical, since the financial inclusion in itself is not enough to reach the economic empowerment and alleviate poverty (IBD report, 2020). Microfinance increases the productivity and livelihoods of the poor (Begum et al., 2019). 
For example, the economic empowerment process developed by the Islamic Development Bank (IDB) [4] is based on: (1) the access to business opportunities: financing will be provided on the basis of prevailing business opportunities rather than the ability to repay the financing (Islamic Development Bank, 2018); (2) finding strategic partners since Islamic microfinance can be an intermediary between the strategic partner and the beneficiaries, and this value chain gives access to business partners for technical support so as to enhance the product quality and marketing (Al Hasnaoui, 2015); (3) providing a supportive investment: the access to infrastructure and its proper utilization will increase the ability of rural poor to pursue their income-generating activities; (4) providing the appropriate finance: financing increases incomes and offers better living conditions (Abdelkader and Ben Salem, 2013); (5) enhancing self-employment through capacity building: El Shabrawy (2011) connotes that microentrepreneurship is the first solution to growing employment among the rural youth and women with no educational, industrial or entrepreneurial background and (6) the market access: even if the poor can use the finance appropriately, they may not be capable of marketing their products (Shirazi et al., 2014). It is argued that this will be a great reassurance for micro-entrepreneurs, as it reduces the risk of uncertainty about the sale of products (Seck, 2017).

Given the differences between the Islamic and conventional microfinance regarding the goals, the target population, the financing methods and the fund sources, their relationship with the economic empowerment might be different.

(1) The empowerment may be for a broader group of the poor, as it considers them extremely poor: Islamic microfinance is able to serve poor people out of poverty (IDB report, 2020). In the conventional system, Bağ $\mathrm{c}$ and Türbedar (2019) highlight that microloans are more beneficial to borrowers living above the poverty line than to those living below the poverty line. Khan (2010) points out that social justice and particularly the elimination of extreme poverty are among the priority areas of Islamic financing strategies.

(2) The scope of moral values in the empowerment process: Abdul Rahim (2010) argues that the moral and ethical attributes of Islamic financing schemes motivate "microentrepreneurs to thrive." The moral and ethical method offered by Islamic financing can efficiently help the poor and micro-entrepreneurs achieve success (Abbas and Shirazi, 2015). The study of the IDB (2021) criticizes the standard microfinance considering a linear relationship between financial inputs and well-being outputs. It submits evidence that this model is implicit, and it faces many obstacles that can be, for example, structural, i.e. the rural-urban divide, geographic variances and road access. They could also be legal, which means banking laws might discriminate against women holding bank accounts and social, i.e. discrimination on the grounds of caste, religion, disability, gender, etc.

(3) Diversified financing modes for empowerment: While the relationship between the microfinance institution and client is as a debtor and creditor, the Islamic relationship is based on trading or investment collaboration (IDB report, 2020). Since the Islamic microfinance offers a variety of financing tools, it allows risk-sharing investments. Indeed, "Islamic microfinance programs can offer solutions in areas where financial inclusion is low, by reducing both risk and debt levels while promoting equality, social welfare and economic security" (OECD, 2020, p.29).

(4) The empowerment with respect to socio-economic impact goals: The Islamic microfinance may be more advantageous compared to the conventional one with regard to financial and social inclusion (Abdullahi and Othman, 2021). The Islamic microfinance can be considered as "social intermediation." The latter refers to 
JBSED

2,1

financial intermediation with a capacity-building component geared toward agents lacking access to savings and borrowing facilities (Elaine and Barton, 1998). Empirically, Alkhan and Hassan (2021) conclude that the Islamic microfinance practice in Kyrgyzstan contributes not only to the economy enhancement, but also to the educational/intellectual level and poverty reduction.

Based on these aspects, we can assert that the Islamic microfinance is more suited to the-low economic empowerment than the conventional microfinance.

In the next section, we will try to empirically access the contribution of Islamic microfinance to the economic empowerment in Tunisia.

\section{Empirical study}

\subsection{Islamic microfinance in Tunisia}

The Tunisian Government faces many economic challenges, especially the poverty and unemployment. The poverty rate in Tunisia reached $18.4 \%$ in the second quarter of 2021 [5].

Launched in 2016, ZT is "a business bank for the vulnerable population" according to the ex-CEO, Nabil Galleb (2017). It has two major competitive advantages. On the one hand, it is the first and unique Islamic microfinance institution in Tunisia using Islamic finance tools. On the other hand, it seeks to institutionalize the approach to financing economic empowerment beyond financial inclusion to economic inclusion. In this respect, since November 2016, ZT has had a central department for business engineering and has launched a special fund of $250 \mathrm{~m}$ dinars for the promotion of entrepreneurship in various areas such as beekeeping, trade, medicinal plants and fisheries [6].

ZT was a winner of the "Best Agricultural and Rural Finance Product" in 2017. It had 220 employees in November 2020 and financed more than 12,000 income-generating projects (of which $40 \%$ of beneficiaries are women). It also provided 40,000 direct and indirect jobs, with a total finance portfolio of about 70m dinars (IDB report, 2020). It intends to open 20 agencies over the Tunisian territory by 2021.

ZT aims to be the leader in Africa and plans to launch an International Center for Economic Empowerment (ICEE) with the intention of promoting research and development in the field of economic empowerment and International Monetary Fund (IMF). What is more, it seeks to establish high-level international partnerships (Galleb, 2017). ZT has implemented 20 value chain projects designed for the poor (IDB Report, 2020).

Every economic empowerment project begins with a pilot phase, i.e. a testing phase that can reveal unexpected problems. [7] Generally, these projects are duplicable and adaptable to change regarding the economic situation. Once successful, the IMF can easily replicate its experience in other locations in the country.

ZT's shareholders are among the most influential players in the economic and financial sectors. Indeed, its capital structure involves a multinational bank called the "Islamic Development Bank," "Zitouna Bank" which is a leading Islamic bank in Tunisia, "Jaida Fund" as a specialized Moroccan microfinance fund and "Zitouna Takaful," which is a leading Islamic insurance company in Tunisia. It also includes "Poulina Holding" as a leading corporation of poultry in Tunisia"; "Délice Holding," which is a leading firm in the dairy industry and the "Fund of deposits and Consignment," which is an investment fund of the Tunisian state. Moreover, ZT has made partnerships with different entities: private sector, civil society and the ministry of agriculture.

ZT offers two types of funding:

(1) Individual financing: it offers only financial services to the beneficiary and

(2) Economic empowerment financing: it is a package of financial and non-financial services. 
3.2 Approach of Zitouna Tamkeen to financing economic empowerment

In ZT, the implementation of an economic empowerment project can be summarized in four steps:

(1) First, with the help of a strategic partner, the ICEE signs smart partnerships. A financial and technical study is established by the ICEE to check the profitability of the project for all parties involved.

(2) Second, the project study is communicated to ZT, which identifies its potential clients for financing.

(3) Third, "Tamkeen for development" performs the training of the beneficiaries of the project.

(4) Fourth, after training and financing, the beneficiaries start the production phase with an existing market, and both strategic partners and ZT provides the assistance and follow-up.

So far, ZT has carried four economic empowerment projects. They are as follows:

(1) Cooperation of Chawwat project: It aims to empower a cooperative "CCO"(Chawwat COopérative) specialized in producing "olive oil" and "pickles." ZT chooses to finance indirectly the cooperative via the workers of CCO. Through Murabaha, ZT has purchased the olives and sold it to $\mathrm{CCO}$ workers who resold it to the cooperative's owners with a profit margin.

(2) Flexinance project: It is the only financing project in the industrial sector specialized in the production of hoses. The beneficiaries are experienced workers choosing to start their own project, which is a subsidiary of the main company. Consequently, the previous employer's company is the guarantor of beneficiaries, and it supports the beneficiaries with raw materials. This economic empowerment model is known as "swarming."

(3) Beepreneur project: It is a project in the beekeeping field. It aims at empowering the beekeepers. Thus, ZT has made a partnership with "IRIS," a start-up specialized in providing technological solutions to boost the productivity of beekeepers and optimize their resources. In this regard, the beneficiaries have received funding for bee boxes from ZT through Murabaha after signing a three-party contract, and the start-up has provided training and technical assistance.

(4) Hlib el khir project: It is the pilot project of ZT. It intends to empower small farmers (2,500 small-scale breeders) and aims to strengthen the production capacity of milk. For this purpose, ZT has made a partnership with "Délice Holding," a leading company in the dairy industry in Tunisia. Thanks to this business partnership, the firm will collect all the milk produced ( $100 \%$ purchase). ZT has imported livestock and donated two cows to each beneficiary through Murabaha. In addition, beneficiaries receive training in a "farmer school" and technical assistance from "Délice" throughout the production phase.

Murabaha has been the only financing product offered by ZT until now. It requires ZT to purchase the item before selling it to the customer. ZT ensures strategic business models that will, ultimately, guarantee the sustainability of the project. As a matter of fact, it tries to enhance the ecosystem by providing the project needs and improving the productivity. 


\section{JBSED 2,1}

\subsection{Empirical evidence}

The qualitative methodology is based on a survey aiming to examine to what extent ZT contributes to the economic empowerment of its beneficiaries.

3.3.1 A-survey sample. For the purpose of answering the research question, some recipients of ZT have been interviewed on various queries touching, e.g., what characterizes ZT and what its important advantage is, and also the financing by Murabaha. Furthermore, the beneficiaries have been asked about the overall contribution of ZT, the improvements in their working conditions and their opinions regarding the training, the technical assistance and the follow-up.

We have interviewed 50 ZT beneficiaries from the 4 projects: 20 beneficiaries of $\mathrm{Hlib}$ el khir, 24 beneficiaries of CCO Chawwat, 4 beneficiaries of Beepreneur and 2 beneficiaries of Flexinance project. ZT is facilitating investment in different activities: Milk, olive oil, beekeeping and hose production. All these beneficiaries were interviewed during the period of April-May, 2020 through telephone but via face-to-face interviews for the CCO Chawwat's beneficiaries. It is worth noting that in 2019, the 140 beneficiaries were divided into 80 CCO (57.17\%), 48 (Hlib el Khir: 34.28\%), and the rest (8.57\%) for 08 (flexinance) and 04 (BeePreneur).

The demographic profiles of respondents show that male clients represent $54 \%$, the female clients $(42 \%)$ and family projects $(4 \%)$. What is more, $62 \%$ are over 40 years of age. At this age group, involvements in business are considered high.

3.3.2 B-Results and discussions. The first question aims to access the degree of awareness of the characteristics of $Z T$. The results indicate that $44 \%$ of the beneficiaries do not know the distinctive features of ZT. According to $40 \%$ of the beneficiaries, one of the important features of ZT is that it targets low income, poor people and youth without interest charge. Yet, only $16 \%$ are "aware" of the economic empowerment of $Z T$ financing, as it not only offers finance, but also it takes care of the project success. This connotes that the respondents' perception of the economic empowerment is weak among the majority of the beneficiaries interviewed. ZT have not conveyed the worthiness of its empowerment approach well.

When we have asked about the most prominent advantage of involving in ZT empowerment projects, the responses have been different regarding the project peculiarities. The majority of participants in CCO Chawwat have noticed that the substantial advantage is the "increased income" owing to the negotiation between ZT and the cooperative owners. The respondents note that their average monthly income has increased significantly. Through access to ZT funding, respondents become able to engage in income-generating activities that, in turn, increase their revenue. Nevertheless, most Hlib el khir participants accentuate that the most advantage offered by ZT is its financial support for project funding. Noting that $22 \%$ of Hlib el khir and Beepreneur, beneficiaries contend that the big benefit is the approach to financing the economic empowerment in light of the training and technical assistance.

Respecting the financing mode, $68 \%$ of respondents' outline that Murabaha is more suitable compared to credit. Through Murabaha, ZT is an intermediary between the production and the marketing in the value chain. For example, in the $\mathrm{CCO}$ project, if the customer approaches ZT, the latter agrees to purchase the olive and resold it to the cooperative's owners with an agreed mark-up. The study reveals a shift in the occupation of the respondents from agriculture to retail businesses.

The indicators of living conditions after ZT financing are appreciated through Likert scale. While $50 \%$ of beneficiaries have confirmed a significant improvement compared to their past conditions, $24 \%$ note a medium improvement, $20 \%$ a weak improvement and $6 \%$ no improvement. According to some Hlib el khir beneficiaries, the project is not generating enough profit, since their expenses are higher than their incomes. This high-cost financing dilemma affects their repayment capacity, mainly at the beginning of the project. 
For the overall contribution of ZT, the majority of the beneficiaries have expressed satisfaction. However, they look for more support and focus attention on some challenges. The first challenge is the lack of funding ( $36 \%$ of responses). The amount of financing is a concern, as it is "too small." For instance, ZT offers ceilings of 20,000 TND (with an exception of 40,000 TND), which is still considered very low for many micro-projects. This small financing amount may hamper the development of the project. Furthermore, respondents face difficulties in working conditions ( $12 \%$ of responses) while technical assistance and training [8] are issues for 10 and $8 \%$ of respondents, respectively.

Using the statistical package for the social sciences program, we have computed the Pearson correlation matrix between the variables so that we can show the possible size effect. The overall contribution of ZT seems to be significantly correlated to the amount of funding, productivity living and working conditions (Table 2).

Subsequently, a linear regression is performed with the objective of looking into the significance of such relationships following Nader (2008).

$$
\text { ZTcont }_{t}=\beta_{1} \mathrm{AF}_{t}+\beta_{2} \mathrm{Pr}_{t}+\beta_{3} \text { Wcond }_{t}+\beta_{4} \mathrm{~T}_{t}+\beta_{4} \mathrm{~F}_{t}+\beta_{5} \text { Lcond }_{t}+Z_{t}
$$

where:

Dependent variable is ZT contribution (ZTcont) and

Independent variables are as follows: Amount of funding (AF), Productivity (Pr), Working condition (WCond), Training (T), Follow-up (F), Living condition (Lcond) and error term $\left(Z_{t}\right)$

The result is as follows:

$$
\begin{aligned}
& \text { ZTcont }_{t}=\mathbf{0 . 6 9} \mathrm{AF}_{t}+\mathbf{1 . 3 1 9} \mathrm{Pr}_{t}+\mathbf{0 . 4 7 8} \mathrm{Wcond}_{t}+0.236 \mathrm{~T}_{t}+0.178 \mathrm{~F}_{t}-\mathbf{0 . 7 1 6} \mathrm{Lcond}_{t}
\end{aligned}
$$

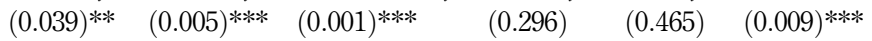

** Significant at the $5 \%$ level and *** significant at the $1 \%$ level.

This finding provides evidence that four dimensions out of six - amount of funding, productivity and working and living conditions - have a significant impact on the overall ZT contribution. Indeed, the overall contribution of ZT is positively linked to the productivity (1.319), the amount of funding (0.69) living and working conditions (0.478).

The ZT empowerment project has the most significant effect on productivity. This means that according to ZT beneficiaries, ZT contribution is notably in the productivity improvement, thanks to the establishment of the chain value and the involvement of strategic partner. For example, in the case of hlib el khir project, the average daily milk production increases from $9 \mathrm{~L} / \mathrm{cow}$ to $15 \mathrm{~L} / \mathrm{cow}$ (Glalleb, 2017). This evidence is in line with Begum et al. (2019)'s evidence.

Moreover, this study concludes that the financial funding is critical for ZT contribution. As long as the amount of funding increases, the contribution is enhanced. Indeed, more income-generating activities enable an increase in the respondent's income. However, as suggested by Rahman et al. (2017), beneficiaries with good inter-personal skills and better empowerment indicators "are more likely to participate in microfinance." which, in turn, may bring about a selection bias.

In addition, we find that ZT contribution is positively and significantly affected by the working conditions. This implies that "access to ZT" project has improved the working conditions thanks to the involvement of strategic partners. The health and working conditions are critical for the productivity and human capital formation.

Nevertheless, empirical evidence indicates that the standard of living is negatively and significantly correlated to the ZT contribution. This is documented by the negative and significant coefficient $(-0.716)$. The small reported operating profit could account for this 
JBSED
2,1

76

Table 2.

Pearson correlation matrix

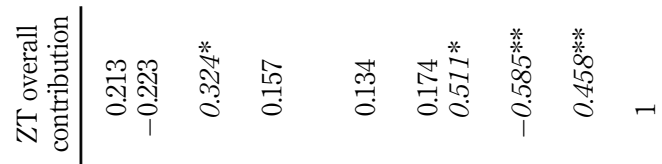

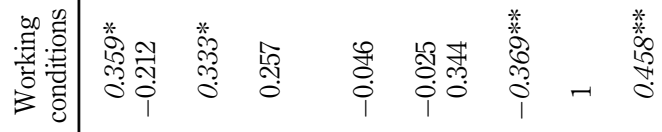

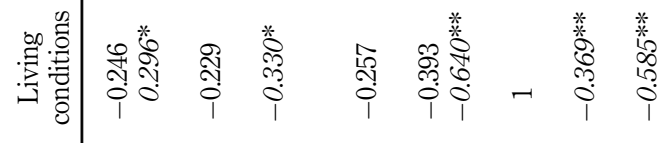

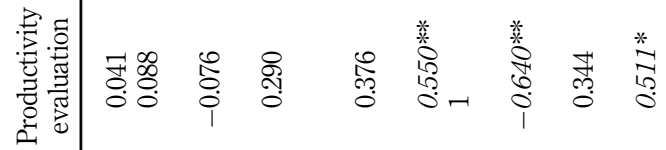

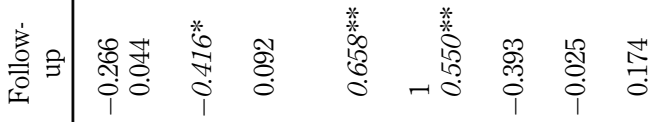

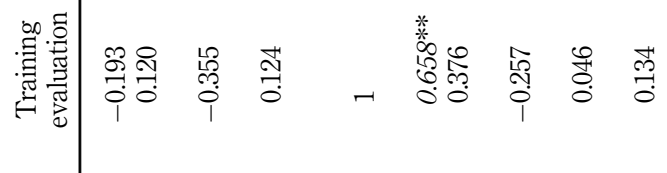

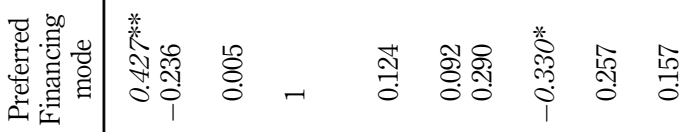

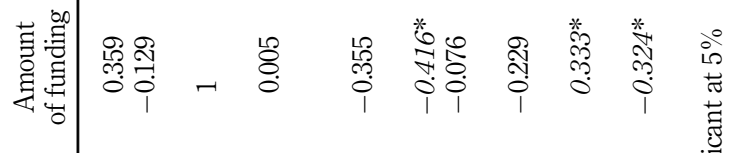

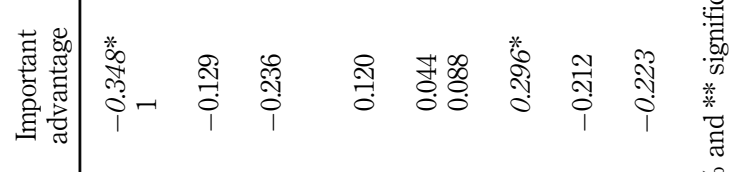

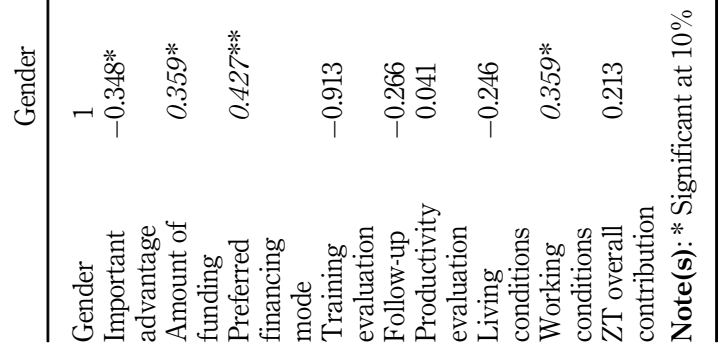


result. This evidence is contrary to the empirical finding of Abdelkader and Ben Salem (2013) and Islam (2020). Islam (2020) finds an improvement in the standard of living in the rural areas of Bangladesh since the beneficiaries spend a high share of their income on consumer spending, which, in turn, increases their standard of living.

Furthermore, the training and follow-up are not correlated with the dependent variable, which may imply that ZT projects do not significantly affect the training and follow-up. On the one hand, this means that assistance is required to strengthen the financial interventions. On another hand, this can be explained by some challenges faced by the economic empowerment projects of ZT. If beneficiaries come with low-entrepreneurial culture, this may reduce their benefits from different steps of economic empowerment. It is argued that both the culture of entrepreneurship and self-employment are an essential engine of wealth accumulation and job creation. Yet, the Global Entrepreneurship Monitor survey (2016) confirms the low level of the entrepreneurial activity in Tunisia. Assistance is required to strengthen the financial interventions.

In sum, some of the indicators of empowerment are significantly improved after participating in microfinance. According to descriptive scores, we confirm the hypothesis that ZT has significantly empowered the respondents. This testifies to the relevance of the economic empowerment process in ZT microfinance. Thus, we argue, following Abdul Rahim (2010), that the Islamic finance contributes to the socio-economic development of the poor and small entrepreneurs. Our findings agree with the studies of Rahman et al. (2017) and Fianto et al. (2018) for women in four districts in rural Bangladesh and rural Indonesia, respectively.

Nevertheless, this case study reveals some challenges. Precisely, the Islamic microfinance institution needs a supportive legal infrastructure to work effectively in Tunisia in order to address the registration fees in Murabaha and the low ceiling of funding. Accordingly, some marketing, operational and technological challenges should be addressed to improve the contribution of ZT to the economic empowerment process. As noted by the OECD report (2020), few Islamic microfinance institutions are delivering finance with a development purpose, "and regulatory frameworks for this tool need to evolve." ZT is called upon to provide its customers with a diverse range of demand driven training. Moreover, ZT can only finance individuals but not small and medium enterprises (SMEs). Nevertheless, such enterprises can play a significant role in enhancing national productivity and generating employment (Usman and Tasmin, 2016). In addition, the Tunisian law does not allow microfinance to offer micro-savings. Fianto (2020) notes that saving with an Islamic IMF influences the type of finance mechanism offered by Islamic IMFs. We believe that if ZT allows micro-saving, this may enhance the empowerment process. Likewise, the only tool used by ZT is Murabaha. Considering the Indonesian case, Fianto et al. (2018) point out that compared to the non-profits and losses sharing (PLS)-financing mechanism, the PLS mechanism has a higher-positive impact on the well-being of rural households. ZT is now in the process of developing istisnaa and salam product. The potential of zakat and waqf institution is yet not available in Tunisia.

\section{Conclusion}

The Islamic microfinance institution is an investor in lieu of a lender. It provides a supportive ecosystem via providing not only financial services, but also skill development, training and follow-up. This research aims to examine to what extent the Islamic microfinance institution can contribute to the economic empowerment in Tunisia.

$\mathrm{ZT}$ is the only Islamic microfinance institution in Tunisia. Furthermore, it is carrying out the economic empowerment approach. Indeed, ZT conducts strategic business models for the purpose of ensuring the project sustainability, giving access to a better quality of project assets through Murabaha financing and building a network of business partners for 
JBSED 2,1 technical support and notably for the marketing of products. Thus, ZT is active in a value chain to empower its customers.

Through a survey of 50 beneficiaries of ZT financing, we look into whether the ZT approach has made the beneficiaries economically empowered. The respondents' perceptions document that ZT has contributed to the economic empowerment for most of their beneficiaries. ZT has especially allowed the productivity raise of participants and improved their working conditions.

However, the training and follow-up are not significantly correlated with ZT contribution. We highlight that providing supportive infrastructure and investment is a prominent component of the economic empowerment process. Consequently, the access to markets and skill development needs to be addressed practically.

It is worth noting that ZT has a limited experience. Thus, it is difficult to access the real impact of financing on the economic empowerment. ZT is called upon to collaborate with more partners so as to sustain the poor and to raise the awareness of the economic empowerment approach of the Islamic microfinance. It is critical that ZT understands the needs and the challenges and offers suitable and affordable instruments to enhance the entrepreneurial skills.

We believe that the Government's role should go beyond by adopting the economic empowerment financing approach as a national strategy for self-employment and poverty alleviation issues. Policymakers may pave the way for extending the Islamic microfinance in Tunisia to empower the unemployed population. We recommend solving the refinancing problem by creating a national guarantee fund dedicated to ZT to enhance its financial sustainability and the well-being of the recipients. Hence, ZT can extent its target population. Regarding the financing model, ZT can explore PLS tools, notably the Mushraka Mutanaqisa mode. Islamic charity funds might support the Islamic microfinance institutions, particularly in targeting the extremely poor. Furthermore, a current financial technology ought to be incorporated in the Islamic microfinance project. According to the Global Islamic Fintech Report of 2019, the development of Islamic Fintech companies could boost the Islamic microfinance growth.

Given the small sample size, it cannot be claimed that these findings represent a complete picture of ZT and customer empowerment. A future study could expand to several areas. This study can be extended by comparing the ZT experience with some Islamic microfinance institutions in other countries. In addition, further research may be conducted to find out whether female dominance in family affairs reduces the state of happiness and overall women's empowerment in the family.

\section{Notes}

1. The other main topics are the sustainable development and role of banks.

2. In Bangladesh, the Nobel Prize economist, "Muhammad Yunus," initiated the famous experiment of Grameen Bank in 1983.

3. For example, in the case of Grammen Bank, $94 \%$ of bank customers are women https:/www.gdrc. org/icm/grameen-supportgrp.html.

4. The Islamic Development Bank is a multilateral development bank established in Jeddah (Saudi Arabia). It is considered as one of the world's most global leaders in Islamic Finance.

5. Source: National Institute of Statistics of Tunisia, http://www.ins.nat.tn/fr/themes/emploi\#1908.

6. https://africanmanager.com/site_eng/zitouna-tamkeen-proposes-creation-of-fund-dedicated-topromotionof-entrepreneurship-announces-nabil-ghalleb/.

7. Zitouna Tamkeen.

8. This question is only addressed to the beneficiaries of Beepreneur and Hib el khir. 


\section{References}

Abbas, K. and Shirazi, N. (2015), "The key players' perception on the role of Islamic microfinance in poverty alleviation”, Journal of Islamic Accounting and Business Research, Vol. 6 No. 2, pp. 244-267.

Abbas, K., Razak, D.A. and Saad, N. (2014), "The perception of micro-entrepreneurs and petty traders on conventional and islamic microfinance: a case study of Pakistan", Journal of Islamic Finance, Vol. 3 No. 1, pp. 38-48.

Abd Elrahman, E. (2015), Islamic Microfinance: Moving beyond Financial Inclusion, Working papers, The Islamic Research and Teaching Institute (IRTI), pp. 1435-1511.

Abdelkader, I.B. and Ben Salem, A. (2013), "Islamic vs conventional microfinance institutions: performance analysis in MENA countries", International Journal of Business and Social Research, Vol. 3 No. 5, pp. 219-233.

Abdul Rahim, A.R. (2010), "Islamic microfinance: an ethical alternative to poverty alleviation", Humanomics: The International Journal of Systems and Ethics, Vol. 26 No. 4, pp. 284-295.

Abdullahi, A. and Othman, A.H.A. (2021), "Determinants of financial sustainability for microfinance institutions lessons for islamic microfinance banks in Nigeria", Turkish Journal of Islamic Economics, Vol. 8 No. Special Issue, pp. 301-320.

Ahmed, H. (2002), "Financing micro enterprises: an analytical study of Islamic microfinance institutions", Journal of Islamic Economic Studies, Vol. 9 No. 2, pp. 27-64.

Al Hasnaoui, A. (2015), Economic Empowerment via Islamic Microfinance, Islamic research and training institute, available at: http://www.irti.org/English/Research/Documents/IDB \% 20GLOBAL \%20FORUM\%20ON \%20ISLAMIC\%20FINANCE/10th_Global_Forum/Economic $\% 20$ Empowerment $\% 20$ Via \%20Islamic\%20Microfinance.pdf.

Alkhan, A.M. and Hassan, M.K. (2021), "Does Islamic microfinance serve maqasid al-shari'a?", Borsa Istanbul Review, Vol. 21 No. 1, pp. 57-68.

Ashraf, M.A. (2014), "Attitudinal dynamics for the rural poor toward participation in MFIs in Bangladesh: implications for Islamic MFIs", Developing Country Studies, Vol. 4 No. 11, pp. 110-125.

Asutay, M. (2010), Islamic Microfinance: Fulfilling Social and Developmental Expectations, Islamic Finance Institution and Market, London: Bloombury, pp. 25-29.

Asutay, M. (2012), "Conceptualising and locating the social failure of Islamic finance: aspirations of Islamic moral economy vs. the realities of Islamic finance", Asian and African Area Studies, Vol. 11 No. 2, pp. 93-113.

Bağc1, K. and Türbedar, E. (2019), Financing for Development: Alternative Perspectives on Challenges and Opportunities of Financing Development, SESRIC Publication, 2019.

Barman, D., Mathur, H.P. and Kalra, V. (2009), "Role of microfinance interventions in financial inclusion: a comparative study of microfinance models", Vision: The Journal of Business Perspective, Vol. 13 No. 3, pp. 51-59.

Beck, T., (2015), Microfinance-A critical literature survey, IEG Working Paper 2015/4.

Begum, H., Alam, F., Bhuiyan, F. and Abdul Ghani, A.B. (2019), "Development of Islamic microfinance: a sustainable poverty reduction approach", Journal of Economic and Administrative Sciences, Vol. 35 No. 3, pp. 143-157.

Cameron, A., Oak, M. and Shan, Y. (2021), "Peer monitoring and Islamic microfinance", Journal of Economic Behavior \& Organization, Vol. 184 No. Issue C, pp. 337-358.

Chowdhry, S. (2006), Creating an Islamic Microfinance Model-The Missing Dimension, Dinar Standard: Business Strategies for the Muslim World.

Demirguc-Kunt, A., Klapper, L. and Singer, D. (2017), Financial Inclusion and Inclusive Growth : A Review of Recent Empirical Evidence, Policy Research Working Paper, No. 8040, World Bank, World Bank, Washington, DC, available at: https://openknowledge.worldbank.org/handle/ $10986 / 26479$.
Islamic microfinance in Tunisia

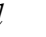


JBSED 2,1

El Shabrawy, A. (2011), "Innovation in Microentrepreneurship \& Islamic Microfinance: The Model of Family Bank", $10^{\text {th }}$ International Entrepreneurship Forum, Tamkeen, Bahrain, 9-11 January 2011.

Elaine, E. and Barton, L. (1998), Social Intermediation and Microfinance Programmes: A Literature Review, USA: Micro-Enterprises Best Practices, The SEEP Network, Arlington, VA.

Fianto, B.A. (2020), "Islamic microfinance institution: survey data from Indonesia", Data in Brief, Vol. 28, p. 104911.

Fianto, B.A., Gan, C., Hu, B. and Roudaki, J. (2018), "Equity financing and debt-based financing: evidence from Islamic microfinance institutions in Indonesia”, Pacific-Basin Finance Journal, Vol. 52, pp. 163-172.

Galleb, N. (2017), Innovative Model for Agriculture Rural Finance, 7th Global Islamic Microfinance Forum November 24-25, 2017, Istanbul - Turkey.

Ghlamallah, E., Alexakis, C., Dowling, M. and Piepenbrink, A. (2021), "The topics of Islamic economics and finance research", International Review of Economics \& Finance, Vol. 75 No. C, pp. 145-160.

Global Islamic Fintech Report (2019), available at: https:/ceif.iba.edu.pk/pdf/IslamicFinTechReport19.pdf.

Hassan, K., Kayed, R.N. and Oseni, U.A. (2013), Introduction to Islamic Banking \& Finance: Principles and Practice, Pearson Higher Education.

Hassan, M.K., Alshater, M., MHasan, R. and Bhuiyan, A.B. (2021), "Islamic microfinance: a bibliometric review”, Global Finance Journal, Vol. 49 No. C, August 2021.

IDB Report (2020), "Economic Empowerment for financial institutions", available at: https:/www.isdb. org/sites/default/files/media/documents/2021-08/Economic \%20Empowerment $\% 20$ For $\%$ 20 Financial $\%$ 20Institutions $\% 20 \% 283 \% 29 \% 20$ Monitoring $\% 20$ and $\% 20$ Evaluation $\%$ 20Toolkit.pdf.

Iqbal, Z. and Mirakhor, A. (2017), Ethical Dimensions of Islamic Finance: Theory and Practice, Springer International Publishing, Cham.

Islam, Md. S. (2020), "Role of islamic microfinance in women's empowerment: evidence from rural development scheme of Islami bank Bangladesh limited", ISRA International Journal of Islamic Finance, Vol. 13 No. 1, pp. 26-45.

Islamic Development Bank Group (2018), Change for Impact: Transforming Agriculture and Rural Development in IsDB Member Countries, Kingdom of Saudi Arabia, Jeddah.

Jouti, A.T. (2019), "An integrated approach for building sustainable Islamic social finance ecosystems", ISRA International Journal of Islamic Finance, Vol. 11 No. 2, pp. 246-266.

Karim, N., Tarazi, M. and Reille, X. (2008), Islamic Microfinance, Working paper no.49, CGAP, August.

Khan, F. (2010), "How 'Islamic' is Islamic banking?", Journal of Behavior \& Economic Organization, Vol. 76 No. 3, pp. 805-820.

Khan, M.S.P. and Beg, S. (2010), "Microfinance: a powerful tool for economic empowerment of the poor", International Journal of Commerce and Business Management, Vol. 3 No. 1, pp. 139-142.

Kulkarni, V.S. (2011), Women's Empowerment and Microfinance: an Asian Perspective Study, Occasional Paper 13, pp. 1-42.

Mansori, S., Safari, M. and Ismail, Z.M.M. (2020), "An analysis of the religious, social factors and income's influence on the decision making in Islamic microfinance schemes", Journal of Islamic Accounting and Business Research, Vol. 11 No. 2, pp. 361-376.

Mukherjee, A.K. (2015), "Empowerment through government subsidized microfinance program", International Journal of Social Economics, Vol. 42 No. 1, pp. 2-18.

Nader, Y. (2008), "Microcredit and wellbeing of women and their families in Cairo", Social Economics Journal, Vol. 37, pp. 644-656.

Narayan, D. (2007), "Empowerment", Journal of Ambulatory Care Management, Vol. 30 No. 2, pp. $120-125$. 
Nur Indah Riwajanti (2013), "Islamic microfinance as an alternative for poverty alleviation: a survey", Afro Eurasian Studies, Vol. 2 Nos 1-2, pp. 254-271.

Obaidullah, M. (2008), Introduction to Islamic Microfinance, IBF Net, New Delhi.

OECD Report (2020), How Islamic Finance Can Help Achieve the Sustainable Development Goals, OECD Development Co-operation Policy Papers, 30, OECD Publishing, Paris.

Rahayu, N.S., (2020), “The intersection of Islamic microfinance and women's empowerment: a case study of Baitul Maal Wat Tamwil in Indonesia", International Journal of Financial Studies, Vol. 8 No. 2, p. 37.

Rahman, A.R.A. (2010), "Islamic microfinance: an ethical alternative to poverty alleviation", Humanomics, Vol. 26, pp. 284-295.

Rahman, M., Khanam, R. and Nghiem, S. (2017), "The effects of microfinance on women's empowerment: new evidence from Bangladesh", International Journal of Social Economics, Vol. 44 No. 12, pp. 1745-1757.

Seck, O. (2017), Islamic Microfinance Experience in a Secular State: Case of Benin, Policy Paper Series No. PP/2017/05, Islamic Research and Training Institute IRTI, Jeddah.

Shinkafi, A.A., Yahaya, S. and Sani, T.A. (2020), "Realising financial inclusion in Islamic finance", Journal of Islamic Marketing, Vol. 11 No. 1, pp. 143-160.

Shirazi, N.S., Elzahi, A. and Khattab, I. (2014), Islamic Microfinance for Sustainable Development, Islamic Research and Training Institute, p. 283.

Tisdell, C. and Ahmad, S. (2018), "Microfinance: economics and ethics", International Journal of Ethics and Systems, Vol. 34 No. 3, pp. 372-392.

Usman, S. and Tasmin, R. (2016), "The relevance of Islamic microfinance in obtaining sustainable development goals", International Journal of Latest Trends in Finance and Economic Sciences, Vol. 6 No. 2, pp. 197-211.

World Bank (2007), "Impact evaluation for microfinance: review of methodological issues", Doing Impact Evaluation, Vol. 7 No. 7. DOI: 10.1192/bjp.112.483.21-a.

World Bank Group (2017), Nigeria's Microfinance Bank Sector: Review and Recommendations, December 2017.

\section{Further reading}

Ahmed, H. (2007), “Awqaf - Based Microfinance: Realizing the Social Role of Islamic Finance”, Paper written for the International Seminar on "Integrating Awqaf in the Islamic Financial Sector, 6-7 March.

Global Islamic Finance Report (GIFR) (2016), "Islamic microfinance: from a market niche to a growing industry", in Dar, H., Azmi, S. and Shafique, B. (Eds), Global Islamic Finance Report 2016, Gerlach Press, Berlin.

IsBD (2020), "Islamic microfinance for women", available at: https://www.isdb.org/sites/default/files/media/ documents/2021-02/ISLAMIC\%20MICROFINANCE\%20FOR\%20WOMEN\%20FINAL.pdf.

UNDP (1995), Human Development Report, Oxford University Press, Oxford.

\section{Corresponding author}

Khoutem Ben Jedidia can be contacted at:khoutembj@yahoo.fr

For instructions on how to order reprints of this article, please visit our website:

www.emeraldgrouppublishing.com/licensing/reprints.htm

Or contact us for further details: permissions@emeraldinsight.com 